Article

\title{
INFLUENCE OF WATER SCARCITY ON MACRONUTRIENTS CONTENTS IN YOUNG LEAVES OF WINE GRAPE CULTIVARS
}

\author{
INFLUÊNCIA DA ESCASSEZ DE ÁGUA NA CONCENTRAÇÃO DE \\ MACRONUTRIENTES EM FOLHAS JOVENS DE CULTIVARES DE UVA PARA \\ VINHO
}

\author{
Serkan Candar ${ }^{1, *}$, Bekir Açıkbaş ${ }^{1}$, Mümtaz Ekiz $^{1}$, Damla Zobar ${ }^{1}$, Illknur Korkutal ${ }^{2}$, Elman Bahar ${ }^{2}$ \\ ${ }^{1}$ Viticulture Research Institute, Department of Cultivation Techniques, Tekirdağ, Turkey. \\ ${ }^{2}$ Tekirdağ Namık Kemal University, Faculty of Agriculture, Department of Horticulture, Tekirdağ, Turkey. \\ * Corresponding author: Tel.: + 905367625376; e-mail: serkan.candar@tarimorman.gov.tr
}

(Received 12.05.2021. Accepted 26.07.2021)

\section{SUMMARY}

This study aimed to determine the variability of plant nutrition content in two-year old local and well-known wine grape cultivars under different water constraint scenarios. Own rooted and potted eight grapevine cultivars (cv. 'Adakarası', 'Papazkarası', 'Karasakı', 'Karalahana', 'Yapıncak', 'Vasilaki', 'Cabernet Sauvignon' and 'Sauvignon Blanc') were subjected to five irrigation treatments (100\% daily irrigation of available water capacity (AWC), $75 \%$ irrigation of AWC, 50\% irrigation of AWC, $25 \%$ irrigation of AWC, and no irrigation for $0 \%$ treatment) for two consecutive years during vegetative growth (May - late September). An increase in nitrogen, potassium and magnesium contents in leaf tissues with decreasing water amount was observed. Similar effect was found for phosphorus and calcium contents. The sulfur concentration in leaf tissues remained almost unchanged. In addition, the variability of genetic potential influenced the nutrient intake of the studied cultivars. The ability of grapevine cultivars to cope with the water deficit of the cultivars should definitely be assessed in adaptation strategies developed to make viticulture sustainable under the effects of the climate crisis.

\section{RESUMO}

O presente estudo visou determinar a variabilidade da concentração de nutrientes em castas autóctones e de referência com dois anos em diferentes condições de restrição de água. Oito castas enraizadas e cultivadas em vaso (cv. 'Adakarası', 'Papazkarası', 'Karasakız', 'Karalahana', 'Yapıncak', 'Vasilaki', 'Cabernet Sauvignon' and 'Sauvignon Blanc') foram submetidas a cinco modalidades de rega (100\% de irrigação diária da capacidade de água disponível (AWC), 75\% de irrigação de AWC, 50\% de irrigação de AWC, 25\% de irrigação de AWC e sem irrigação) em dois anos consecutivos durante o período de crescimento vegetativo (maio - final de setembro). Foi observado um aumento das concentrações de azoto, potássio e magnésio nos tecidos da folha com a diminuição da quantidade de água aplicada. Efeito semelhante foi detetado nos teores de fósforo e de cálcio. A concentração de enxofre nos tecidos foliares manteve-se praticamente inalterada. Além disso, a variabilidade do potencial genético influenciou o consumo de nutrientes das castas estudadas. A capacidade das castas para enfrentar o déficit hídrico deve ser definitivamente avaliada nas estratégias de adaptação desenvolvidas para tornar a viticultura sustentável sob os efeitos da crise climática.

Keywords: water scarcity, grapevine genetic resources, climate change, grapevine nutrition.

Palavras-chave: escassez de água, recursos genéticos da videira, alteração climática, nutrição da videira.

\section{INTRODUCTION}

The importance of biodiversity and local cultivars have been repeatedly emphasized by many researchers (Ergül et al., 2011; Balda et al., 2014; Y1lmaz et al., 2020). The reason for the increasing trend towards local cultivars is that although it has been a natural phenomenon throughout history, climate change is happening faster than ever before and a greater human impact on this alteration exists. To ensure the sustainability of viticulture in the Mediterranean climate, it is necessary to benefit from the adaptability and genetic diversity of local cultivars (Bernardo et al., 2018).

The vast majority of vineyards in the world are located in areas with Mediterranean climate

This is an Open Access article distributed under the terms of the Creative Commons Attribution License (https://creativecommons.org/licenses/by/4.0), which permits unrestricted use, distribution, and reproduction in any medium, provided the original work is properly cited 
characteristics where the current winemaking regions risk losing their viticultural sustainability in future scenarios (Fraga et al., 2016; Santos et al., 2020). These risks are largely due to severe dryness, heat waves, severe soil water deficit (Tóth and Végvári, 2016) and unwanted precipitation during vegetation (Candar et al., 2019a). Although these patterns are becoming a major challenge for agriculture (Korres et al., 2016), also climate crisis comes with possibilities as well as risks. Warmer climates may not have positive impacts on traditional wine regions, but northern regions, where growing grapes could not be done before, may have opportunities for viticultural suitability.

On the other hand, complex relations between soil, grapevine functions, physiological responses and berry quality strongly interact with soil water content (Oertel et al., 2016; Paustian et al., 2016). Soil water content and soil water holding capacity may take an important role in mineralization rate besides soil temperature, organic matter content, and pore size. However, soil moisture and nutrient availability are, undoubtedly, two major edaphic factors determining crop yield and quality interactively.

Although topics such as fertilization, nutrient availability, availability and usefulness of different fertilizers on grapevine yield and quality were extensively investigated, their effects on vine physiology and productivity have been less studied (Brataševec et al., 2013; Martínez et al., 2016; Zamudio et al., 2021).

Changes in nutrient utilization reveal a potential for related changes in vine productivity and berry quality. These potential yield and quality levels are determined by climate, environmental $\mathrm{CO}_{2}$ and cultivar characteristics. Yield and quality are also often limited by root zone resources, such as nutrients and water, and are further reduced by pests and diseases.

Understanding the relationships among vine, water and nutritional resources to struggle with climate change under such extreme conditions and increase adaptation opportunities is now an even more important challenge for fruit production (Carvalho $e t$ al., 2019; Villette et al., 2020).

The aim of this research was to understand how to improve the existing knowledge on plant macro mineral nutrition and soil fertility management under different water constraint practices of wine grape cultivars grown in Turkey Thrace Region.

\section{MATERIALS AND METHODS}

The experiment was conducted from 2019 to 2020 on potted, own-rooted wine grapes in an open field in Tekirdağ Viticulture Research Institute (TVRI),
Turkey. The autochthonous cultivars of region 'Adakarası', 'Papazkarası', 'Karasakı', 'Karalahana', 'Yapıncak', 'Vasilaki', and reference cultivars in the world, 'Cabernet Sauvignon' and 'Sauvignon Blanc', were used. Because of their different behavior patterns in the face of water deficiency, they were subjected to five irrigation treatments: $100 \%$ daily irrigation of available water capacity (AWC), 75\% irrigation of $\mathrm{AWC}, 50 \%$ irrigation of $\mathrm{AWC}, 25 \%$ irrigation of $\mathrm{AWC}$, and no irrigation for $0 \%$ treatment.

The experimental setup was established with a total of 960 vines, consisting of three replications and eight vines for each replication and five treatments, according to the randomized blocks trial pattern.

The plant material of the wine cultivars was pruned from the TVRI vineyards, cuttings with 7-8 buds were taken from healthy vines that previously tested for important viruses and known as virus-free. Cuttings were rooted in peat:perlite (1:1) mixture by applying $4000 \mathrm{ppm}$ of indole-3-butyric acid (IBA) with the fast dipping method, and keeping them under $24-26{ }^{\circ} \mathrm{C}, 70 \%$ humidity at $8 \mathrm{~h}$ light and $16 \mathrm{~h}$ dark short-day conditions for about four weeks. Rooted and shooted cultivars were transplanted to 14 litres pots with agricultural perlite (Kale Perlit Ltd., Istanbul, Turkey). The cuttings were half planted in perlite and half outside. In the period when adventitious root development started, 2-3 shoots were cut from the top and thus the new 2-3 shoots, consisted of 1-2 buds remaining, were developed more strongly. When the clusters became visible, EL 15-17 (Lorenz et al., 1995), all of them were detached and removed, also excess shoots were removed and 2-3 shoots were left in each vine. When the shoots reached approximately $170-175 \mathrm{~cm}$ (EL 29-31), the shoot top was taken and the same shoot length was preserved until the end of the experiment with lateral leaves.

A computer-controlled irrigation and fertilization system was used for plant nutrition (Teori Yazılım Ltd., Istanbul, Turkey). Disease, pest and weed control have been maintained as in local standards in both years. Considering the growing state of the plants and the climatic characteristics of the year, minimal manipulations were made in nutrient solutions during the vegetation periods.In both years, four different plant nutrition solutions were applied according to modifications of Hoagland and Arnon (1950). The modifications made in the solution were decided according to the plant development status, phenological period and research purposes. Table I shows the application date ranges of modified solutions. 
Table I

Nutrition solutions and application ranges

\begin{tabular}{cccccc}
\hline \multicolumn{3}{c}{ 2019 vegetation period } & \multicolumn{3}{c}{ 2020 vegetation period } \\
\hline Dates & Applied solution & Duration & Dates & Applied solution & Duration \\
\hline $15.05-18.06$ & Solution 1 & For 5 weeks & $11.06-19.06$ & Solution 1 & For 2 weeks \\
$18.06-30.07$ & Solution 2 & For 6 weeks & $19.06-16.07$ & Solution 2 & For 4 weeks \\
$30.07-20.09$ & Solution 3 & For 8 weeks & $16.07-01.09$ & Solution 3 & For 6 weeks \\
$20.09-21.10$ & Solution 4 & For 6 weeks & $02.09-09.10$ & Solution 4 & For 5 weeks \\
\hline
\end{tabular}

The nutrient solutions were analyzed three times during the vegetation periods in both years to control the amount of plant nutrients expected to be provided (Table II).

Table II

Nutrient solutions applied during the vegetation periods of 2019-2020 and application dates

\begin{tabular}{cccccccc}
\hline \multirow{2}{*}{ Nutrients } & Range* & \multicolumn{2}{c}{ Sample solution 1 (ppm) } & \multicolumn{2}{c}{ Sample solution 2 (ppm) } & \multicolumn{2}{c}{ Sample solution 3 (ppm) } \\
\cline { 2 - 7 } & & 2019 & 2020 & 2019 & 2020 & 2019 & 2020 \\
\hline$\sum \mathrm{N}$ & $50-200$ & $-*$ & 83.00 & 85.90 & 129.00 & 112.10 & 148.00 \\
$\mathrm{P}$ & $40-60$ & 17.50 & 13.76 & $-*$ & 21.57 & 18.20 & 19.33 \\
$\mathrm{~K}$ & $175-350$ & 15.70 & 95.71 & 152.50 & 140.35 & 137.00 & 102.13 \\
$\mathrm{Ca}$ & $100-150$ & 50.00 & 72.23 & 58.00 & 74.59 & 99.40 & 118.45 \\
$\mathrm{Mg}$ & $30-90$ & 16.50 & 13.65 & 34.70 & 13.74 & 65.60 & 31.25 \\
$\mathrm{~S}$ & $75-150$ & 18.50 & 47.83 & 21.70 & 44.16 & 45.00 & 31.83 \\
$\mathrm{Fe}$ & $1-12$ & 3.85 & 8.21 & 12.60 & 6.05 & 5.60 & $-*$ \\
$\mathrm{Cu}$ & $0.02-0.2$ & 0.22 & 0.02 & 0.15 & 0.19 & 0.15 & 0.10 \\
$\mathrm{Zn}$ & $0.05-1$ & 0.46 & 0.07 & 0.14 & 0.59 & 0.29 & 0.50 \\
$\mathrm{Mn}$ & $0.4-1$ & 0.86 & 0.16 & 0.42 & 0.60 & 0.41 & 0.46 \\
$\mathrm{~B}$ & $0.008-0.5$ & 0.25 & 0.05 & 0.16 & 0.26 & 0.18 & 0.26 \\
$\mathrm{Mo}$ & $0.001-0.2$ & 0.38 & $-* *$ & 0.11 & 0.72 & 0.38 & 0.78
\end{tabular}

*Expected amounts of nutrients according to Hoagland and Arnon, (1950); **Missing analysis results were not given as they seemed contradictory

When all plants reached a homogeneous shoot length, the daily irrigation scheme per pot was reduced to decided percentages to create water stress (Table III)

With the planting of cuttings in pots in an open field, the irrigation amount calculated as four litres for a day according to Ilahi and Ahmad (2017) was arranged to the amounts shown in Table III by observing reference evapotranspiration (ETo), water amount in overflow plate under pots and physical condition of the plants. The maximum irrigation amount (eight liters, 100\% AWC) was decided according to the growth power and phenological period. The daily irrigation amounts were applied to the plants by using drippers that irrigate at four litres per hour and the irrigation times were calculated on the main computer.

Table III

Daily amount and periods of water applied during both vegetation periods

\begin{tabular}{cccccc}
\hline & & \multicolumn{3}{c}{2020 vegetation period } \\
\hline \multirow{2}{*}{ Dates } & $\begin{array}{c}\text { Irrigation time } \\
(\mathrm{min})\end{array}$ & $\begin{array}{c}\text { Irrigation amount } \\
(\mathrm{L})\end{array}$ & Dates & $\begin{array}{c}\text { Irrigation time } \\
(\mathrm{min})\end{array}$ & $\begin{array}{c}\text { Irrigation } \\
\text { amount }(\mathrm{L})\end{array}$ \\
\hline $15.05-14.06$ & 75 & 5.00 & $29.06-01.07$ & 75 & 5.00 \\
$14.06-28.06$ & 110 & 7.33 & $01.07-18.07$ & 110 & 7.33 \\
$28.06-16.09$ & 120 & 8.00 & $18.07-02.10$ & 120 & 8.00 \\
$16.09-04.10$ & 100 & 6.67 & $02.10-14.10$ & 100 & 6.67 \\
$04.10-11.10$ & 40 & 2.67 & $14.10-24.10$ & 40 & 2.67 \\
$11.10-31.10$ & 30 & 2.00 & $24.10-30.10$ & 30 & 2.00 \\
\hline
\end{tabular}


The total daily irrigation amount for each date range was divided into five equal doses each day by adjusting irrigation minutes, and applied at: 10:00 am; 02:00 pm; 06:00 pm; 9:00 pm; 12:00 pm. With the start of irrigation constraint, the pots were tied with plastic bags so that the vine shoots were exposed, and the growing media in pots were prevented from unwanted precipitation, although there was no rainfall during water constraints in both years. In both years, when all plants reached a shoot length of 170-175 cm, the amount of water given as eight litres per day in $100 \%$ irrigation was reduced by $75 \%, 50 \%, 25 \%$ and $0 \%$. Reduced irrigation treatments were continued until the end of two vegetation periods (Table IV). The data of $0 \%$ treatment were not shared in this study, as the leaves fall on all plants.

Table IV

The amount and periods of water applied during both vegetation periods for AWC treatments

\begin{tabular}{ccccc}
\hline $\begin{array}{c}\text { Water constraints } \\
\text { period }\end{array}$ & $\begin{array}{c}\text { Water constraints } \\
\text { period }\end{array}$ & Treatment & $\begin{array}{c}\text { Daily irrigation time } \\
(\mathrm{min})\end{array}$ & Daily irrigation amount (L) \\
\hline & & $100 \%$ & 120 & 8.00 \\
28.07 .2019 & 18.07 .2020 & $75 \%$ & 90 & 6.00 \\
- & - & $50 \%$ & 60 & 4.00 \\
16.09 .2019 & 02.10 .2020 & $25 \%$ & 30 & 2.00 \\
& & $0 \%$ & 0 & 0.00 \\
\hline
\end{tabular}

\section{Climate Data}

Descriptive meso-climatic weather data such as temperature, relative humidity, light intensity, wind speed and total precipitation at two meters high from the ground were monitored for two consecutive years with a weather station installed within the experimental area.

\section{Analysis of macronutrients in the leaf}

Leaf sampling was made from whole leaves (blade+petiol) because it was not possible to obtain enough sample using only petioles from young plants. In addition, Cancela et al. (2018) reported that leaf blades would be preferable to petioles for macronutrient detection. After the development of the vine shoots, five, six and seven fully developed mature leaves (Dami and Smith, 2019) were used backwards from the tip of the main shoot in late August and early September. Leaf samples taken from the plants were brought to the laboratory, first passed in tap water, then in $0.1 \mathrm{~N} \mathrm{HCl}$ solution to remove the superficial contamination and finally washed through distilled water, then dried the air in the shade and at $70{ }^{\circ} \mathrm{C}$ in a laboratory oven until the weight loss ends. The dried samples were grinded and prepared for analysis (Benito et al., 2013). Total nitrogen $(\mathrm{N})$ was obtained by Kjeldahl distillation method, phosphorus $(\mathrm{P})$, potassium $(\mathrm{K})$, calcium $(\mathrm{Ca})$, magnesium $(\mathrm{Mg})$, and sulfur $(\mathrm{S})$ elements in the leaf samples were detected in ICP-OES
(Inductively Coupled Plasma) equipment in Namık Kemal University Central Research Laboratory.

\section{Statistical Analysis}

The obtained data were subjected to variance analysis using the SPSS 16.0 software (SPSS Inc., Chicago, USA) and the differences between means were compared through the Duncan's test.

\section{RESULTS AND DISCUSSION}

In the first year of the study, the highest air temperature in AWC treatments period varied between $29.04{ }^{\circ} \mathrm{C}$ and $34.52{ }^{\circ} \mathrm{C}$, and the average temperature during this period was calculated as $30.72{ }^{\circ} \mathrm{C}$. Air relative humidity varied between $30.62 \%$ and $42.61 \%$, and the average was $39.05 \%$. The highest light intensity was measured as 1727.13 $\mu \mathrm{mol} / \mathrm{m}^{2} / \mathrm{s}$ and the lowest was $653.56 \mu \mathrm{mol} / \mathrm{m}^{2} / \mathrm{s}$ and its average was calculated as $1433.80 \mu \mathrm{mol} / \mathrm{m}^{2} / \mathrm{s}$. Wind speed varied between $1.53 \mathrm{~m} / \mathrm{s}$ and $7.36 \mathrm{~m} / \mathrm{s}$ in the experiment field. In 2020, the average temperature was calculated as $24.23{ }^{\circ} \mathrm{C}$ and the average relative humidity as $68.23 \%$. In this period, the average light intensity was $1360.35 \mu \mathrm{mol} / \mathrm{m}^{2} / \mathrm{s}$, and the average wind speed was calculated as $2.51 / \mathrm{m}^{2} / \mathrm{s}$. Comparison of AWC treatment periods of the two years revealed that the warmer and clearer days of 2019 were higher and the lighting intensity was also higher. Average relative humidity was lower in 2019 (Figure 1). 

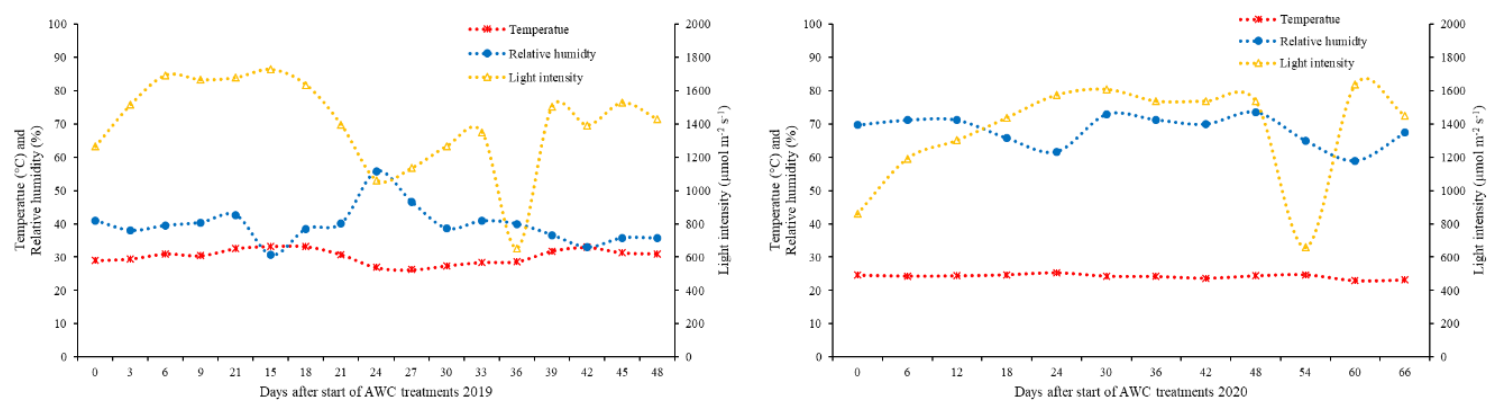

Figure 1. Climate data of temperature $\left({ }^{\circ} \mathrm{C}\right)$, relative humidity $(\%)$ and light intensity $\left(\mu \mathrm{mol} / \mathrm{m}^{2} / \mathrm{s}\right)$ in both vegetation years.

In both years, the highest total $\mathrm{N}(\%)$ values were detected in $25 \%$ AWC treatment in terms of the main effects of treatments. While other treatments belonged to the same group, the amount of nitrogen in the leaf tended to decrease with the increasing amount of water. 'Cabernet Sauvignon' was the exception of this phenomenon, in which total $\mathrm{N}$ content did not decrease with increasing AWC. When the two-year means were examined in terms of cultivar, the highest leaf total $\mathrm{N}$ contents were found in 'Sauvignon Blanc', 'Karalahana' and 'Cabernet Sauvignon' cultivars, and the lowest total $\mathrm{N}$ contents in 'Adakarası' cultivar (Table V).

Table V

Effect of cultivars and treatments on the total N\%

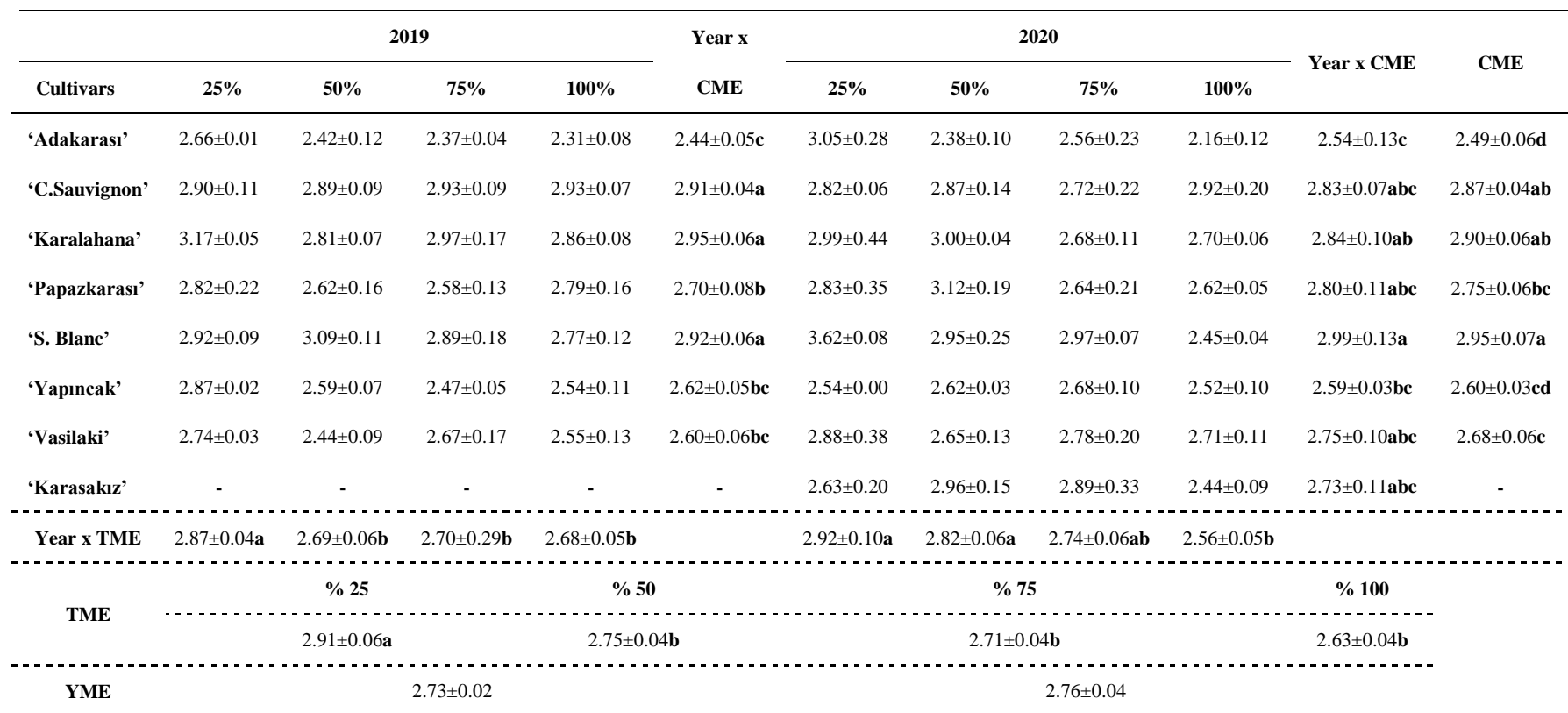

*Values marked with different letters in the same column and row were statistically significant at $\mathrm{p}<0.05$ level according to the Duncan's test. Results expressed as mean \pm standard error. CME: Cultivar main effect, TME: Treatment main effect, YME: Year main effect. Main effects were grouped as averages of two years, and interactions were grouped within the year to which they belong.

Although there are many reference values for the macronutrients of the petiole and the leaf blade at different phenological stages (Christiansen, 2005; Brunetto et al., 2015; Leibar et al., 2017; Schreiner and Scagel, 2017; Domagała-Swiątkiewicz et al., 2019), it was not possible to compare with the reference values because this study was carried out during one-two years in young vines growing in a hydroponic system.
In addition to the opinions stating that the increased total $\mathrm{N}$ amount reduces the resistance to drought in plants (Wilkinson et al., 2007), some studies suggest that $\mathrm{N}$ increases drought resistance by regulating the root water intake mechanisms of the plant (Ding et al., 2018). In this study, results supporting both views were determined. Helwi et al. (2015) also reported that total $\mathrm{N}$ content in the leaf blade of 
'Sauvignon Blanc' cultivar is higher than 'Cabernet Sauvignon'.

On the other hand, it was determined that the relationship between $\mathrm{N}$ content, photosynthetic capacity and vegetative growth was affected by the cultivar. Especially the low total N content and weak vegetative growth of 'Yapıncak' and 'Vasilaki' cultivars were remarkable while 'Adakarası'cultivar had a very strong growth force, although with a low total $\mathrm{N}$ content.

The effect of cultivars and treatments on the amount $\mathrm{P}(\%)$ in the leaf is shown in Table VI. Regarding the effect of irrigation amount on P content in the leaf, the results showed that $100 \%$ AWC treatment causes higher $\mathrm{P} \%$ content both in years and in terms of the main effect of the year, $\mathrm{P}$ amount in leaves tends to decrease with decreasing irrigation practices, and this trend was statistically significant. This trend applies to all cultivars in both years.

The highest leaf phosphorus content in both years and the mean of years was found in 'Adakarası' cultivar. The lowest leaf phosphorus content was observed in 'Papazkarası' cultivar.

Table VI

Effect of cultivars and treatments on the total $\mathrm{P} \%$

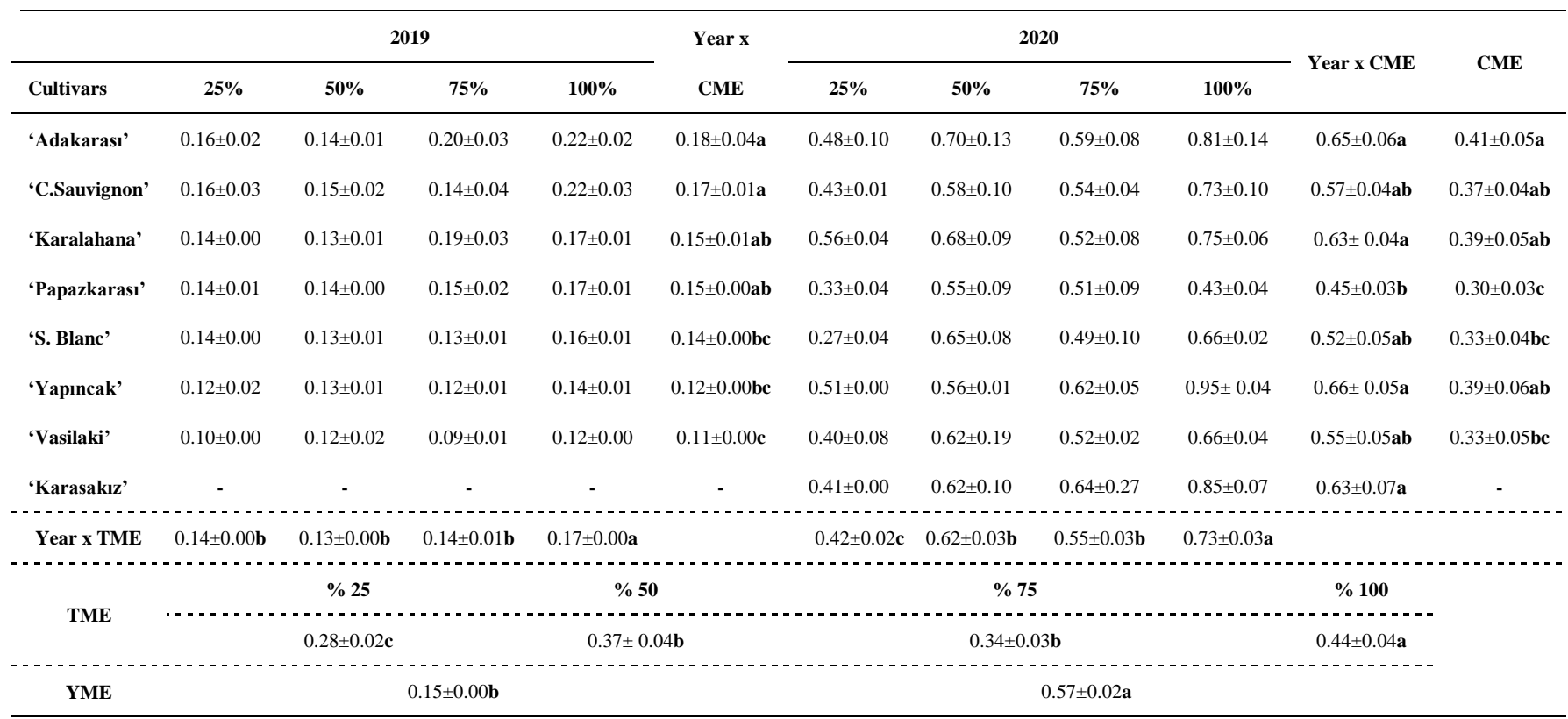

*Values marked with different letters in the same column and row were statistically significant at p<0.05 level according to the Duncan's test. Results expressed as mean \pm standard error. CME: Cultivar main effect, TME: Treatment main effect, YME: Year main effect. Main effects were grouped as averages of two years, and interactions were grouped within the year to which they belong.

$\mathrm{P}$ is an important macronutrient that constitutes approximately $0.2 \%$ of the total plant biomass. It is the building block of important macromolecules such as nucleic acids, phospholipids, adenosine triphosphate (ATP). It also takes part in many biochemical reactions and metabolic cycles (Kuwahara et al., 2016). Like total N, P deficiency is often associated with the restriction of plant growth. A better understanding of $\mathrm{N}$ and $\mathrm{P}$ cycles is important to understanding the responses to drought stress in terms of soil-plant relationships ( $\mathrm{He}$ and Dijkstra, 2014). 100\% AWC irrigation caused higher $\mathrm{P}$ content in terms of both years and the year main effect, $P$ amount in leaves tends to exhibit a statistically significant decrease with decreasing irrigation practices. This trend applies to all cultivars in both years. This result is consistent with the view that drought causes a decrease in $\mathrm{P}$ uptake and $\mathrm{CO}_{2}$ assimilation (He and Dijkstra, 2014). On the other hand, while the 'Adakarası' and 'Cabernet Sauvignon' cultivars stand out from the other studied cultivars by their high and statistically significant $\mathrm{P}$ contents in terms of the cultivar main effect, it can be thought that this phenomenon is related to the high amounts of photosynthesis (A) of these cultivars. 'Karalahana' cultivar, on the other hand, exhibits different responses with relatively low amounts of seasonal photosynthesis despite its relatively high $\mathrm{P}$ content.

Many different studies reported that the decrease in soil moisture content causes a decrease in $\mathrm{N}$ and $\mathrm{P}$ uptake in plants (Ahmad Waraich et al., 2011; Sardans and Peñuelas, 2012). According to the available data, this information is valid in terms of $\mathrm{P}$ contents, while $\mathrm{N}$ contents indicate different results. This situation may be due to: the fact that vine is a perennial plant; cultivar genotype differences; differences in drought stress manipulation; duration 
and severity of drought; experimental differences such plant age, climatic conditions etc. However, Rouphael et al. (2012) reported that the drought affected $\mathrm{N}$ and $\mathrm{P}$ uptake, its distribution and use within the plant, and this suppresses the plant through growth, development and physiological processes. In vine, the relationships between drought, stress, nutrients and cultivars can be evaluated as more complex.

$\mathrm{K}$ value was found highest in 'Sauvignon Blanc' for 2019 and in 'Cabernet Sauvignon' for 2020. Means of two years also represent the highest $\mathrm{K}$ content for 'Cabernet Sauvignon' while the 'Adakarası' and 'Yapıncak' cultivars had the lowest. Treatment main effect values indicate that the $\mathrm{K}$ content decreased significantly with increasing water amount. This was valid for all cultivars except $25 \%$ and 50\% AWC for 'Vasilaki' and 'Sauvignon Blanc' cultivars during the 2020 vegetation period (Table VII).

Table VII

Effect of cultivars and treatments on the total K\%

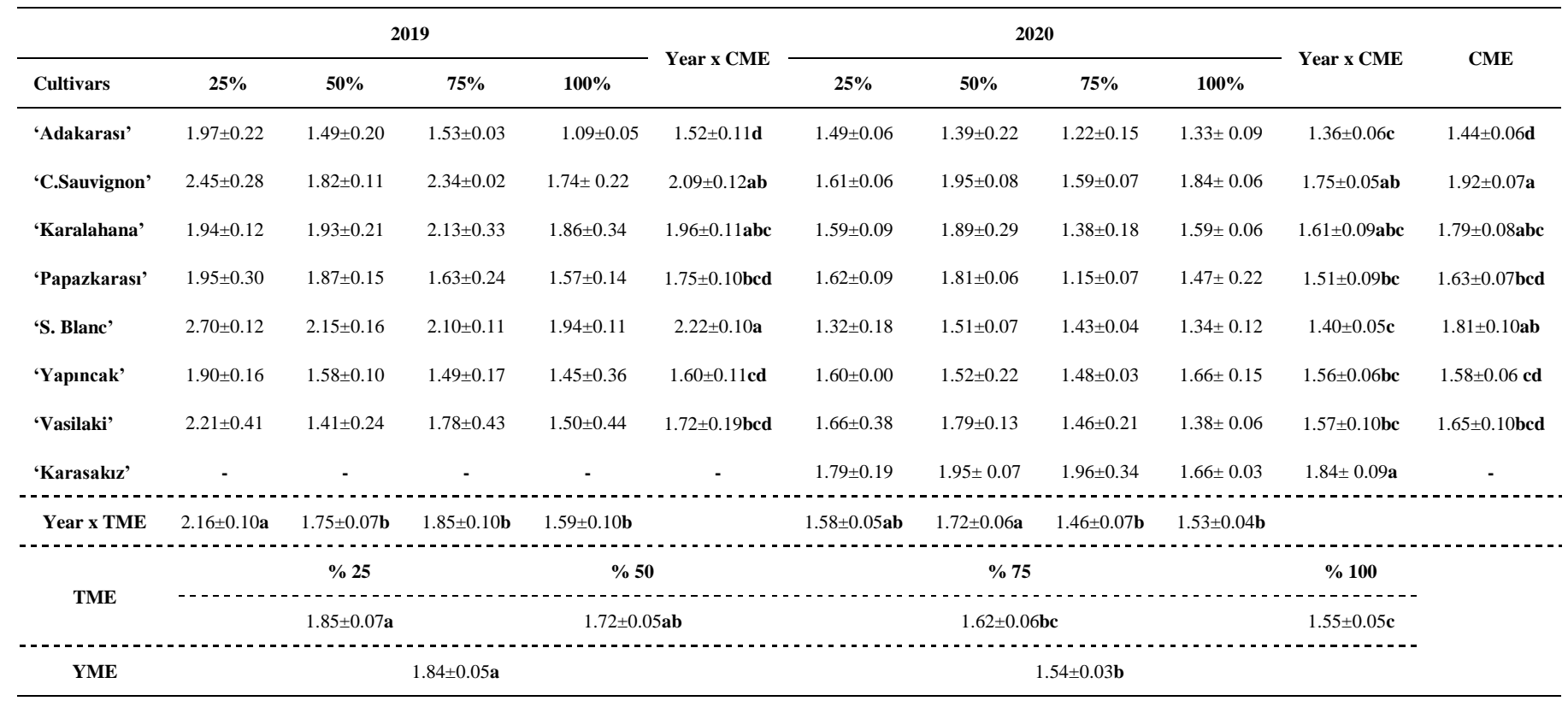

*Values marked with different letters in the same column and row were statistically significant at p<0.05 level according to the Duncan's test. Results expressed as mean \pm standard error. CME: Cultivar main effect, TME: Treatment main effect, YME: Year main effect. Main effects were grouped as averages of two years, and interactions were grouped within the year to which they belong.

$\mathrm{K}$ is one of the most important indicators of berry quality in grape (Davies et al., 2006; Edwards et al., 2011; Romero et al., 2012). Besides, it plays a role in the transport of photosynthesis products by increasing sucrose transport capacity in the phloem, in the distribution of carbohydrates to shoots and roots and cell growth (Cakmak et al., 1994). The effect of soil $\mathrm{pH}$ on the berry quality is also related to the $\mathrm{K}$ content (Kodur et al., 2013). Excessive potassium intake causes high juice $\mathrm{pH}$, loss of colour and quality in wine, especially in warm climates (Martins et al., 2012). Consequently, $\mathrm{K}$ is an important resource for the production of photosynthetic products in all plants. It can be expected that $\mathrm{K}$ deficiency, produced carbohydrates and the dry matter will limit plant growth by negatively affecting the development of organs such as leaves and roots; on the other hand, increasing $\mathrm{K}$ is effective in improving and maintaining photosynthetic electron transfer by decreasing NAD(P)H activity (Cakmak et al., 1994; Cakmak, 2010), stoma and leaf movements, homeostasis of cells, enzyme activations, and protein synthesis (Villette et al., 2020).

Although studies are reporting that $\mathrm{K}$ uptake, distribution and accumulation in different vine organs increase with rising water amount and soil water availability (Dundon et al., 1984; Esteban et al., 2001; Klein et al., 2000; Candar et al., 2019b), under dry conditions, such as those created in this study, increases in $\mathrm{K}$ content as a stress-management strategy against decreasing amount of water were detected (Cakmak, 2005; Trifilò et al., 2011). The results suggest that the decrease in water in the total plant biomass with the decreasing amount of water makes some nutrients including $\mathrm{K}$ more concentrated and cause them to increase proportionally. On the other hand, it should be 
highlighted that the genetic predisposition of different cultivars within the same species also affects their $\mathrm{K}$ content.

The results of $\mathrm{Ca}$ analysis in leaf samples indicated that, in terms of cultivar main effect, stronger growing cultivars, such as 'Adakarası',
'Karalahana', 'Cabernet Sauvignon' and 'Sauvignon Blanc', had higher Ca content in both years and mean of years. In terms of the treatment main effect, the higher contents in $100 \%$ AWC than $25 \%$ AWC are in accordance with the literature, but fluctuations in $50 \%$ and $75 \%$ applications were remarkable (Table VIII).

Table VIII

Effect of cultivars and treatments on the total $\mathrm{Ca} \%$

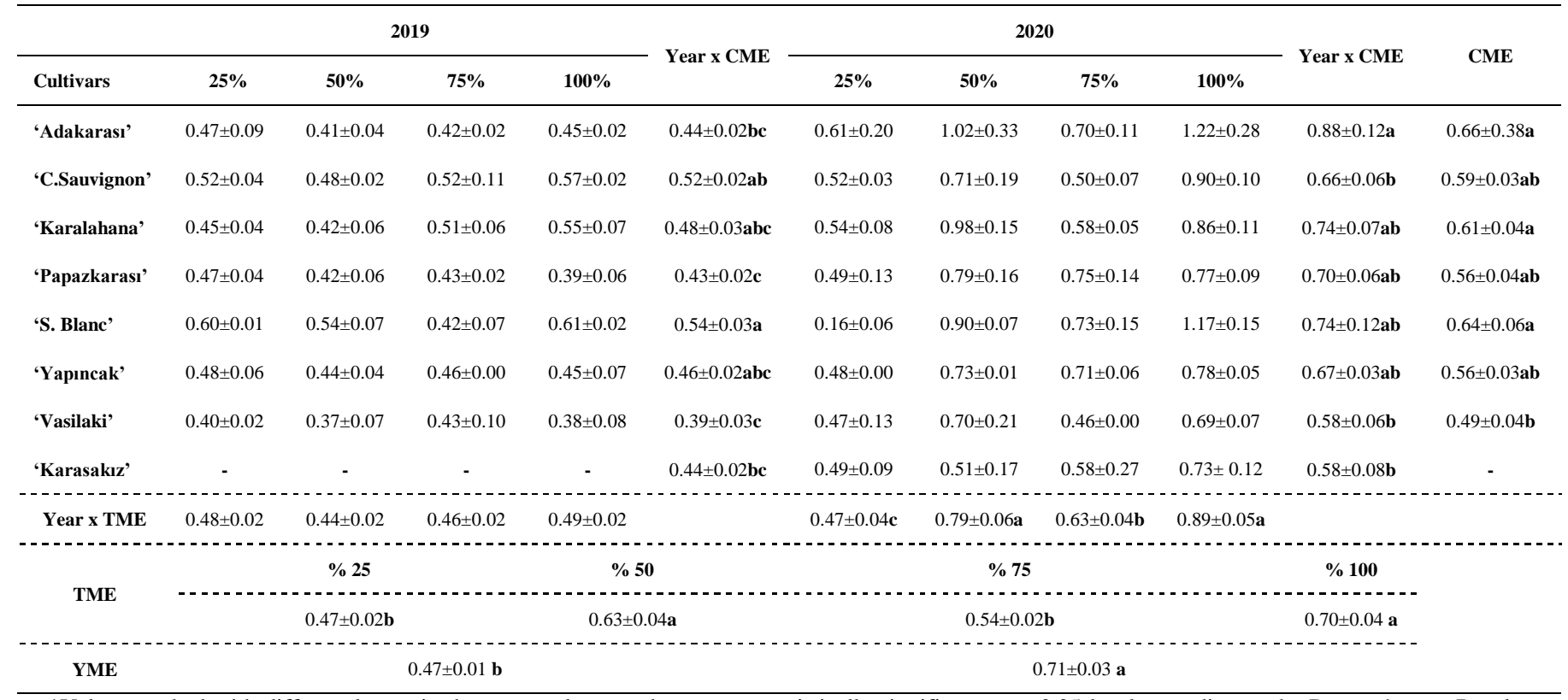

*Values marked with different letters in the same column and row were statistically significant at p<0.05 level according to the Duncan's test. Results expressed as mean \pm standard error. CME: Cultivar main effect, TME: Treatment main effect, YME: Year main effect. Main effects were grouped as averages of two years, and interactions were grouped within the year to which they belong.

$\mathrm{Ca}$ is a vital macro element for plants, and it works both as a structural component of the cell wall and cell membranes and as a channel that enables communication between cells. Ca deficiency in plant tissues and organs is generally not caused by the deficiency in the soil (White and Broadley, 2003). Direct and indirect effects, such as high temperature, relative humidity, an insufficient amount of water available in the root zone, weak root growth, salinity, $\mathrm{pH}$, low stomatal conductivity and transpiration amounts, rapid plant growth and development, affect Ca uptake and its distribution to plant tissues (Altintas and Candar, 2012). Therefore, deficiency symptoms are mostly found in developing tissues such as young leaves and fruits (Thor, 2019), which can be ascribed to the fact that $\mathrm{Ca}$ is a divalent ion and cannot be carried in phloem tissue easily. $\mathrm{Ca}$ structurally interacts with carboxyl groups, pectin and phospholipids, providing flexibility and stiffness to the cell membrane and stabilizes it. Low $\mathrm{Ca}$ content weakens the cell wall and prevents the growth of rapidly developing organs such as pollen tube or capillary roots (Bascom et al., 2018). Beyond these structural roles, managing and directing responses to biotic and abiotic stress is another important function of $\mathrm{Ca}$ (Thor, 2019). In terms of the cultivar main effects, it was observed that stronger cultivars, such as 'Adakarası', 'Karalahana', 'Cabernet Sauvignon' and 'Sauvignon Blanc', had higher Ca content in both years and in the mean of years. This situation can be ascribed to the faster development of xylem tissues depending on the growth force of the cultivars and the easier transportation of $\mathrm{Ca}$ from transport tissues compared to weakly growing cultivars. It was also found that the relatively high stomatal conductivity and generally high water use efficiency of these cultivars facilitate $\mathrm{Ca}$ transport. It was determined that $\mathrm{Ca}$, which has a low transport rate in plant tissues, accumulated more in the second trial year.

In terms of treatment main effect, the results revealed that the $\mathrm{Mg}$ content decreases significantly with increasing irrigation amount. Regarding the cultivar main effect, although the small differences found, 'Sauvignon Blanc' cultivar and 'Yapıncak' cultivar had the highest and the lowest Mg content, respectively (Table IX). 
Table IX

Effect of cultivars and treatments on the total $\mathrm{Mg} \%$

\begin{tabular}{|c|c|c|c|c|c|c|c|c|c|c|c|}
\hline \multirow[b]{2}{*}{ Cultivars } & \multicolumn{4}{|c|}{2019} & \multirow{2}{*}{ Year x CME } & \multicolumn{4}{|c|}{2020} & \multirow{2}{*}{ Year x CME } & \multirow{2}{*}{ CME } \\
\hline & $25 \%$ & $\mathbf{5 0 \%}$ & $75 \%$ & $100 \%$ & & $25 \%$ & $50 \%$ & $75 \%$ & $100 \%$ & & \\
\hline ‘Adakarası' & $0.19 \pm 0.02$ & $0.16 \pm 0.01$ & $0.14 \pm 0.00$ & $0.13 \pm 0.00$ & $0.15 \pm 0.0 \mathbf{c}$ & $0.15 \pm 0.01$ & $0.16 \pm 0.05$ & $0.14 \pm 0.02$ & $0.19 \pm 0.02$ & $0.16 \pm 0.01 \mathbf{a}$ & $0.16 \pm 0.00 \mathbf{a b c}$ \\
\hline 'C.Sauvignon' & $0.21 \pm 0.01$ & $0.15 \pm 0.00$ & $0.20 \pm 0.00$ & $0.15 \pm 0.01$ & $0.18 \pm 0.00 \mathbf{b c}$ & $0.14 \pm 0.00$ & $0.16 \pm 0.04$ & $0.10 \pm 0.01$ & $0.19 \pm 0.00$ & $0.15 \pm 0.01 \mathbf{a b}$ & $0.16 \pm 0.00 \mathbf{a b c}$ \\
\hline 'Karalahana' & $0.23 \pm 0.02$ & $0.19 \pm 0.03$ & $0.18 \pm 0.00$ & $0.18 \pm 0.02$ & $0.19 \pm 0.01 \mathbf{a b}$ & $0.12 \pm 0.00$ & $0.19 \pm 0.02$ & $0.10 \pm 0.00$ & $0.15 \pm 0.03$ & $0.14 \pm 0.01 \mathbf{a b}$ & $0.17 \pm 0.01 \mathbf{a b}$ \\
\hline 'Papazkarası' & $0.19 \pm 0.01$ & $0.16 \pm 0.01$ & $0.14 \pm 0.00$ & $0.13 \pm 0.02$ & $0.15 \pm 0.00 \mathrm{c}$ & $0.12 \pm 0.02$ & $0.16 \pm 0.03$ & $0.10 \pm 0.01$ & $0.12 \pm 0.01$ & $0.12 \pm 0.01 \mathbf{b}$ & $0.14 \pm 0.00 \mathbf{c}$ \\
\hline 'S. Blanc' & $0.27 \pm 0.00$ & $0.22 \pm 0.01$ & $0.18 \pm 0.01$ & $0.20 \pm 0.00$ & $0.22 \pm 0.01 \mathbf{a}$ & $0.10 \pm 0.04$ & $0.16 \pm 0.01$ & $0.12 \pm 0.01$ & $0.18 \pm 0.03$ & $0.14 \pm 0.01 \mathbf{a b}$ & $0.18 \pm 0.01 \mathbf{a}$ \\
\hline 'Yapıncak' & $0.21 \pm 0.01$ & $0.17 \pm 0.01$ & $0.14 \pm 0.01$ & $0.14 \pm 0.02$ & $0.16 \pm 0.01 b c$ & $0.12 \pm 0.00$ & $0.10 \pm 0.00$ & $0.13 \pm 0.01$ & $0.12 \pm 0.01$ & $0.11 \pm 0.00 \mathbf{b}$ & $0.14 \pm 0.00 \mathbf{c}$ \\
\hline 'Vasilaki' & $0.22 \pm 0.01$ & $0.16 \pm 0.03$ & $0.18 \pm 0.04$ & $0.15 \pm 0.03$ & $0.18 \pm 0.01 \mathbf{b c}$ & $0.11 \pm 0.02$ & $0.19 \pm 0.03$ & $0.10 \pm 0.01$ & $0.11 \pm 0.01$ & $0.13 \pm 0.01 \mathbf{a b}$ & $0.15 \pm 0.01 \mathbf{b c}$ \\
\hline 'Karasakiz' & - & - & - & - & - & $0.11 \pm 0.02$ & $0.10 \pm 0.00$ & $0.11 \pm 0.03$ & $0.13 \pm 0.02$ & $0.11 \pm 0.01 \mathbf{b}$ & - \\
\hline Year x TME & $0.21 \pm 0.00 \mathbf{a}$ & $0.17 \pm 0.00 \mathbf{b}$ & $0.17 \pm 0.00 \mathbf{b}$ & $0.15 \pm 0.00 \mathbf{b}$ & & $0.12 \pm 0.00 \mathbf{b}$ & $0.15 \pm 0.01 \mathbf{a}$ & $0.11 \pm 0.00 \mathbf{b}$ & $0.15 \pm 0.00 \mathbf{a}$ & & \\
\hline \multirow[b]{2}{*}{ TME } & \multicolumn{5}{|c|}{$\% 25$} & \multicolumn{3}{|c|}{$\% 75$} & \\
\hline & \multicolumn{5}{|c|}{$\begin{array}{r}0.17 \pm 0.00 \mathrm{a} \\
0\end{array}$} & & $0.14 \pm 0.0$ & & \multicolumn{2}{|r|}{$\begin{array}{c}\% 100 \\
0\end{array}$} & \\
\hline YME & & & $0.18 \pm 0.00 \mathbf{a}$ & & & & & $.13 \pm 0.00 \mathrm{~b}$ & & & \\
\hline
\end{tabular}

*Values marked with different letters in the same column and row were statistically significant at $\mathrm{p}<0.05$ level according to the Duncan's test. Results expressed as mean \pm standard error. CME: Cultivar main effect, TME: Treatment main effect, YME: Year main effect. Main effects were grouped as averages of two years, and interactions were grouped within the year to which they belong.

$\mathrm{Mg}$ is an important macronutrient element and has functions in many physiological processes. As chlorophyll is the central atom, it is active in photosynthesis processes and directs a series of enzymatic reactions (Zlámalová et al., 2015). Mg deficiency decreases the total chlorophyll content in the leaves. This decrease is caused by the decrease in chlorophyll a and the proportional increase of chlorophyll b. Mg-induced chlorosis occurs either directly from the $\mathrm{Mg}$ deficiency in the soil or due to the antagonistic effects of $\mathrm{Ca}$ and $\mathrm{K}$ (Garcia et al., 1999; Ksouri et al., 2005). Due to its role in chlorophyll activity, the need for $\mathrm{Mg}$ is also high in plants grown under high light conditions, and sufficient $\mathrm{Mg}$ level improves the transport of photosynthetic carbohydrates to consumption organs such as roots and fruits (Cakmak and Yazici, 2010). It has been determined that only $5 \%$ of the $\mathrm{Mg}$ amount in the total canopy of the grapevine comes from perennial storage organs (Schreiner et al., 2006). The need for $\mathrm{Mg}$ during the rapid growth period also accelerates the uptake and transport of this nutrient. Regarding the treatment main effect, the $\mathrm{Mg}$ content decreases significantly with increasing irrigation amount, which can be assigned to the distribution of $\mathrm{Mg}$ to newly developing and rapidly increasing vegetative organs with increasing irrigation practices, that is lower than its uptake or transport. Concerning the cultivar main effect, although the small differences observed, the 'Sauvignon Blanc' cultivar and the 'Yapıncak' cultivar had the highest and the lowest Mg contents, respectively. As in all nutrition elements, genotypic differences for $\mathrm{Mg}$ are known to affect uptake and use (Livigni et al., 2019). In addition, increasing light intensity increases the need for $\mathrm{Mg}$ in tissues (Cakmak and Yazici, 2010). This fact may explain the increasing amount of photosynthesis and water use efficiency of 'Sauvignon Blanc' cultivar with increasing light intensity.

Although the significant effect of cultivars and treatments on $\mathrm{S}$ content, the observed differences occurred at a very small range in terms of treatment main effect and did not change directly with the AWC quantities. Therefore, the changes caused by the treatments cannot be explained by the available data based on this experimental procedure. However, if year and cultivar interactions are analyzed within themselves, the $\mathrm{S}$ content generally tended to decrease with the increasing amount of water in 2019 vegetation period, while $\mathrm{S}$ content tended to increase with the increasing amount of water in 2020 vegetation, except for the 'Yapıncak' cultivar in 2020. On the other hand, in terms of the cultivar main effect, 'Cabernet Sauvignon', 'Sauvignon Blanc', 'Karalahana' and 'Papazkarası' cultivars had slightly higher content, and the other cultivars formed a second statistical group (Table X). 
Table X

Effect of cultivars and treatments on the total S\%

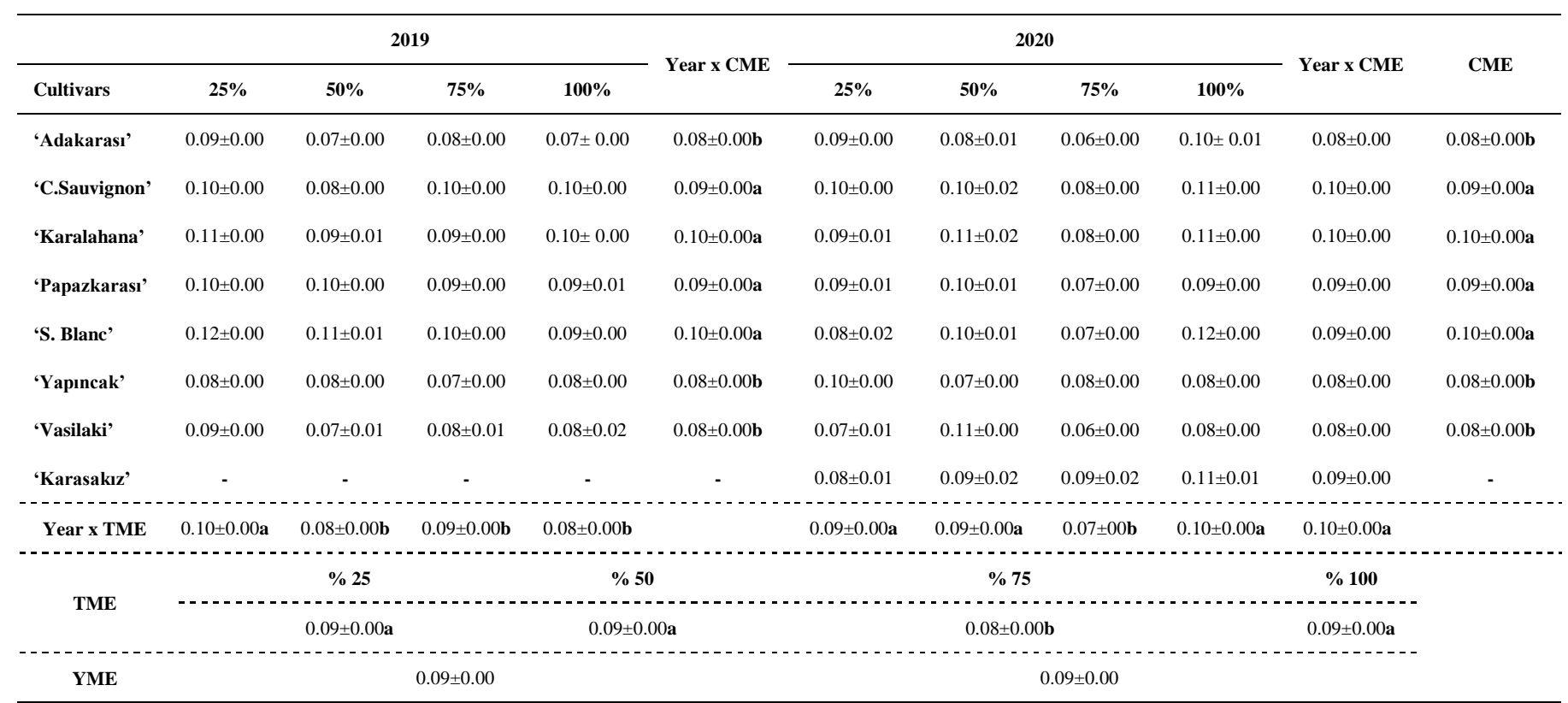

*Values marked with different letters in the same column and row were statistically significant at p<0.05 level according to the Duncan's test. Results expressed as mean \pm standard error. CME: Cultivar main effect, TME: Treatment main effect, YME: Year main effect. Main effects were grouped as averages of two years, and interactions were grouped within the year to which they belong.

$\mathrm{S}$ is one of the macronutrients that are cyclical in nature and important for plant functions. It is found in proteins and chlorophyll and plays an important role in energy metabolism. The symptoms of its deficiency may resemble $\mathrm{N}$ deficiency. It can be taken from the soil in the form of sulfate (SO4-2) through the roots and from the atmosphere in form of sulfur dioxide (SO2) through stomata (Inal et al., 2003). It plays an important role in the defence mechanisms of plants against stress and pests due to its functions in enzyme activity. Metabolites like sulfur glutathione act against oxidative stress and heavy metal toxicity. Some volatile compounds rich in sulfur may also provide resistance against pathogens and herbivores (Zhao et al., 2008). As previously stated, the available data for $\mathrm{S}$ is not sufficient to make a consistent discussion. 'Cabernet Sauvignon', 'Sauvignon Blanc', 'Karalahana' and 'Papazkaras1' cultivars have relatively higher leaf S content.

\section{CONCLUSIONS}

All of the changes in the nutrient content in the leaves may be due to the effect of arid conditions, and in some cases also due to their genetic characteristics. Some nutrients can be determined in high amounts due to the increase in the dry matter content of the leaves in the plants when they have more water in the root zone.

Differences in leaf contents of all cultivars were found statistically significant in terms of cultivar main effect. It was observed that all nutrients, except total $\mathrm{N}$ and $\mathrm{S}$, were significantly affected by the year. Macronutrients, except $\mathrm{K}$ and $\mathrm{Mg}$, reached higher values in the second year of the experiment. This situation possibly resulted from the increasing root amount of the plants in the second year and the plant nutrients that started to accumulate in the increasing perennial parts.

The predictable effects of the climate crisis suggest that the temperature rise and imbalances in the atmospheric water budget will affect water and nutrition flow as well as the usefulness and availability of soil water in terms of vine. Therefore, it is thought that the differences displayed by cultivars in terms of uptake, transportation, use and storage of macro and micro plant nutrients are important and should be examined in detail through different trial designs.

\section{ACKNOWLEDGEMENTS}

This study was carried out under the project TAGEM/BBAD/B/19/A1/P6/06, which was supported and funded by the General Directorate of 
Agricultural Research and Policies of the Republic of Turkey Ministry of Agriculture and Forestry. The authors would like to thank all editors, reviewers, and the agronomists Jannat Khan, Ecem Kübra Demirkap1 and Şevval Vural for their contribution to the field and laboratory works. Authors would also like to thank Ersin Karacabey for corrections in the text.

CONFLICTS OF INTEREST: The authors declare no conflict of interest.

\section{REFERENCES}

Ahmad Waraich E., Ahmad R., Ashraf M.Y., 2011. Role of mineral nutrition in alleviation of drought stress in plants. Australian J. Crop. Sci., 5, 764-777.

Altintas S., Candar S., 2012. Relations between growth, N level, NH4-N ratio of fertilizer, climatic variables, harvest time and tipburn of cos lettuce grown under the cold glasshouse. J. Food Agric. Environ., 10, 368-373.

Balda P., Ibáñez J., Sancha J.C., Toda F.M., 2014. Characterization and identification of minority red grape varieties recovered in Rioja, Spain. Am. J. Enol. Vitic., 65, 148-152.

Bascom C.S., Hepler P.K., Bezanilla M., 2018. Interplay between ions, the cytoskeleton, and cell wall properties during tip growth. Plant Physiol., 176, 28-40.

Benito A., Romero I., Domínguez N., Escudero E.G., Martín I., 2013. Leaf blade and petiole analysis for nutrient diagnosis in Vitis vinifera L. cv. Garnacha tinta. Aust. J.Grape Win Res., 19, 285-298.

Bernardo S., Dinis L. T., Machado N., Moutinho-Pereira J., 2018. Grapevine abiotic stress assessment and search for sustainable adaptation strategies in Mediterranean-like climates. A review. Agron. Sustain. Dev., 38, 66.

Brataševec K., Sivilotti P., Vodopivec B.M., 2013. Soil and foliar fertilization affects mineral contents in Vitis vinifera L. cv. "Rebula" leaves. J. Plant. Nutr. Soil Sci., 13, 650-663.

Brunetto G., Melo G.W.B., De Toselli M., Quartieri M. Tagliavini M., 2015. The role of mineral nutrition on yields and fruit quality in grapevine, pear and apple. Rev. Bras. Frutic., 37, 1089-1104.

Carvalho A., Leal F., Matos M., Brito J.L, 2019. Heat stress tolerance assayed in four wine-producing grapevine varieties using a cytogenetic approach. Ciência Téc. Vitiv. 34, 61-70.

Cakmak I., 2005. Role of mineral nutrients in tolerance of crop plants to environmental stress factors. Fertigation Proceedings: Selected Papers of the IPI-NATESC-CAU-CAAS. International Symposium on Fertigation. Beijing-China. 20-24 September. Available at: https://www.ipipotash.org/uploads/udocs/IPI_Proceeedings_ Fertigation_Symposium_China_Sept_05_p1-7.pdf (accessed on 11.05.2021).

Cakmak I., Hengeler C., Marschner H., 1994. Changes in phloem export of sucrose in leaves in response to phosphorus, potassium and magnesium deficiency in bean plants. J. Exp. Bot., 45, 1251-1257.

Cakmak I., Yazici A.M., 2010. Magnesium: A Forgotten element in crop production. Better Crops with Plant Food. 94, 23-25.

Cancela J.J., Fandiño M., González X.P., Rey B.J., Mirás-Avalos A.J. M., 2018. Seasonal variation of macro and micronutrients in blades and petioles of Vitis vinifera $\mathrm{L}$. cv. Mencía and Sousón. J. Plant. Nutr. Soil Sci., 181, 498-515.

Candar S., Alço T., Yaşasın A.S., Korkutal İ., Bahar E., 2019a. Evaluation of long term changes for viticultural climate indices in Turkey Thrace (in Turkish with English abstract). COMU Agri., 7, 259-268.

Candar S., Bahar E., Korkutal İ., Alço T., Uysal Seçkin G., $2019 \mathrm{~b}$. The effects of different green pruning practices on oenological properties of Merlot (Vitis vinifera L.) grape juice (in Turkish with English abstract). Mediterr. Agric. Sci., 32, 121-127.

Christiansen P., 2005. Use of tissue analysis in viticulture. Proceedings of Varietal Winegrape Production Short Course University of California Davis Extension, 30-37. Available at: http://cecentralsierra.ucanr.edu/files/96235.pdf (accessed on 11.05.2021)

Dami I., Smith M., 2019. Grapevine Nutrient Management: Petiole Sampling and Analysis. Ohio State University Extension. Available at: https://ohioline.osu.edu/factsheet/hyg-1438 (accessed on 11.05.2021).

Davies C., Shin R., Liu W., Thomas M.R., Schachtman D.P., 2006. Transporters expressed during grape berry (Vitis vinifera L.) development are associated with an increase in berry size and berry potassium accumulation. J. Exp. Bot., 57, 3209-3126.

Ding L., Lu Z., Gao L., Guo S., Shen Q., 2018. Is nitrogen a key determinant of water transport and photosynthesis in higher plants upon drought stress? Front. Plant Sci., 9, 1-12.

Domagała-Swiątkiewicz I., Gąstoł M., Kiszka A., 2019. Effect of nitrogen and potassium fertilization on the magnesium content in vineyard soil, and in the leaves and berries of Bianca and Sibera grapevine cultivars. J. Elem., 24, 755-769

Dundon C.G., Smart R., McCarthy M., 1984. The effect of potassium fertilizer on must and wine potassium levels of Shiraz grapevines. Am. J.Enol.Vitic., 35, 200-205.

Edwards, E.J., Downie A.F., Clingeleffer, P.R., 2011. A simple microplate assay to quantify nonstructural carbohydrates of grapevine tissues. Am. J .Enol. Vitic., 62, $133-137$

Ergül A., Perez-Rivera G., Söylemezoğlu G., Kazan K., Arroyo-Garcia R., 2011. Genetic diversity in Anatolian wild grapes (Vitis vinifera subsp. sylvestris) estimated by SSR markers. Plant Genet. Resour., 9, 375-383.

Esteban M.A., Villanueva M.J., Lissarrague, J.R., 2001. Effect of irrigation on changes in the anthocyanin composition of the skin of $\mathrm{cv}$ Tempranillo (Vitis vinifera $\mathrm{L}$ ) grape berries during ripening. J. Sci. Food Agric., 81, 409-420

Fraga H., Atauri I.G.C., Malheiro A.C., Santos J.A., 2016. Modelling climate change impacts on viticultural yield, phenology and stress conditions in Europe. Glob. Change Biol., 22, 3774-3788.

Garcia M., Daverede C., Gallego P., Toumi M., 1999. Effect of various potassium-calcium ratios on cation nutrition of grape grown hydroponically. J. Plant Nutr., 22, 417-425.

He M., Dijkstra F.A., 2014. Drought effect on plant nitrogen and phosphorus: A meta-analysis. New Phytol., 204, 924-931.

Helwi P., Thibon C., Habran A., Hilbert G., Guillaumie S., Delrot S., Darriet P., Van Leeuwen C., 2015. Effect of vine nitrogen status, grapevine variety and rootstock on the levels of berry S-glutathionylated and S-cysteinylated precursors of 3-sulfanylhexan-1-ol. J. Int. Sci. Vigne. Vin., 49, 253-265.

Hoagland D.R., Arnon D.I., 1950. The water-culture method for growing plants without soil. Circular. California 
Agricultural Experiment Station, 347. Available at: https://archive.org/details/watercultureme $3450 \mathrm{hoag} / \mathrm{mode} / 2 \mathrm{u}$ $\mathrm{p}$ (accessed on 21.06.2021)

Ilahi W.F.F., Ahmad D., 2017. A study on the physical and hydraulic characteristics of cocopeat perlite mixture as a growing media in containerized plant production. Sains Malays., 46, 975-980.

Inal A., Günes A., Alpaslan M., Adak M.S., Taban S., Eraslan F., 2003. Diagnosis of sulfur deficiency and effects of sulfur on yield and yield components of wheat grown in central Anatolia, Turkey. J. Plant Nutr., 26, 1483-1498.

Klein I., Strime M., Fanberstein L., Mani Y., 2000. Irrigation and fertigation effects on phosphorus and potassium nutrition of wine grapes. Vitis, 39, 55-62.

Kodur S., Tisdall J.M., Clingeleffer P.R., Walker R., 2013. Regulation of berry quality parameters in 'Shiraz' grapevines through rootstocks (Vitis). Vitis, 53, 125-128.

Korres N.E., Norsworthy J.K., Tehranchian P., Gitsopoulos T.K., Loka D.A., Oosterhuis D.M., Gealy D.R., Moss S.R., Burgos N.R., Miller R.M., Palhano M., 2016. Cultivars to face climate change effects on crops and weeds: A review. Agron. Sustain. Dev., 36, 11-22.

Ksouri R., Gharsalli M., Lachaal M., 2005. Physiological responses of Tunisian grapevine varieties to bicarbonate-induced iron deficiency. J. Plant Physiol., 162, 335-341.

Kuwahara F.A., Souza G.M., Guidorizi K.A., Costa C., Meirelles P.R. de L., 2016. Phosphorus as a mitigator of the effects of water stress on the growth and photosynthetic capacity of tropical C4 grasses. Acta Sci. Agron., 38, 363-370.

Leibar U., Pascual I., Aizpurua A., Morales F., Unamunzaga O., 2017. Grapevine nutritional status and $\mathrm{K}$ concentration of must under future expected climatic conditions texturally different soils. J. Soil Sci. Plant Nutr., 17, 385-397.

Livigni S., Lucini L., Sega D., Navacchi O., Pandolfini T., Zamboni A., Varanini, Z., 2019. The different tolerance to magnesium deficiency of two grapevine rootstocks relies on the ability to cope with oxidative stress. BMC Plant Biol., 19, 1-17.

Lorenz D.H., Eichhorn K.W., Bleiholder H., Klose R., Meier U., Weber E., 1995. Growth stages of the grapevine: phenological growth stages of the grapevine (Vitis vinifera L. ssp. vinifera) - Codes and descriptions according to the extended BBCH scale. Aust. J. Grape Wine Res., 1, 100-103.

Martínez, E.M., Rey, B.J., Fandiño, M., Cancela, J.J., 2016. Impact of water stress and nutrition on Vitis vinifera cv. 'Albariño': Soil-plant water relationships, cumulative effects and productivity. Span. J. Agric. Res., 14, 2-15.

Martins V., Cunha A., Gerós H., Hanana M., Blumwald E., 2012. Mineral compounds in the grape berry. In: The Biochemistry of the grape berry. 23-43. Gerós H., Chaves M.M., Delrot S. (eds.). Bentham Science Publishers Ltd.

Oertel C., Matschullat J., Zurba K., Zimmermann F., Erasmi S., 2016. Greenhouse gas emissions from soils-A review. Geochemistry, 76, 327-352.

Paustian K., Lehmann J., Ogle S., Reay D., Robertson G.P., Smith P., 2016. Climate-smart soils. Nature 532, 49-57.

Romero P., Fernández J.I., Martinez-Cutillas A., 2012. Physiological thresholds for efficient regulated deficit irrigation management in winegrapes under semiarid conditions: Soil-plant-water relationships and berry composition. Acta Hortic., 931, 171-178.

Rouphael Y., Cardarelli M., Schwarz D., Franken P., Colla G., 2012. Effects of drought on nutrient uptake and assimilation in vegetable crops. In: Plant Responses to Drought Stress. 171-195. Aroca R. (ed.) Springer, Berlin.
Santos J.A., Fraga H., Malheiro A.C., Moutinho-Pereira J., Dinis L.T., Correia C., Moriondo M., Leolini L., Dibari C., Costafreda-Aumedes S., Kartschall T., Menz C., Molitor D., Junk J., Beyer M., Schultz H.R., 2020. A review of the potential climate change impacts and adaptation options for European viticulture. Appl. Sci., 10, 3092.

Sardans J., Peñuelas J., 2012. The role of plants in the effects of global change on nutrient availability and stoichiometry in the plant-soil system. Plant Physiol., 160, 1741-1761

Schreiner R.P., Scagel C.F., Baham J., 2006. Nutrient uptake and distribution in a mature "Pinot noir" vineyard. HortScience, 41, 336-345.

Schreiner R.P., Scagel C.F., 2017. Leaf blade versus petiole nutrient tests as predictors of nitrogen, phosphorus, and potassium status of 'Pinot noir' grapevines. HortScience, $\mathbf{5 2}$, 174-184

Thor K., 2019. Calcium-nutrient and messenger. Front. Plant Sci., 10, 1-7.

Tóth J.P., Végvári Z., 2016. Future of winegrape growing regions in Europe. Aust. J. Grape Wine Res., 22, 64-72.

Trifilò P., Nardini A., Raimondo F., Lo Gullo M.A., Salleo S., 2011. Ion-mediated compensation for drought-induced loss of xylem hydraulic conductivity in field-growing plants of Laurus nobilis. Func. Plant Biol., 38, 606-613.

Villette J., Cuéllar T., Verdeil J.L., Delrot S., Gaillard I., 2020. Grapevine potassium nutrition and fruit quality in the context of climate change. Front. Plant Sci., 11, 1-9.

White P.J., Broadley M.R., 2003. Calcium in plants. Ann. Bot., 92, 487-511.

Wilkinson S., Bacon M.A., Davies, W.J., 2007. Nitrate signalling to stomata and growing leaves: Interactions with soil drying, ABA, and xylem sap pH in maize. J. Exp. Bot., 58, 1705-1716

Yılmaz F., Shidfar M., Hazrati N., Kazan K., Yüksel C.Ö., Uysal T., Özer C., Yaşasın A.S., Söylemezoğlu G., Boz Y., Celik H., Ergül A., 2020. Genetic analysis of central Anatolian grapevine (Vitis vinifera $\mathrm{L}$.) germplasm by simple sequence repeats. Tree Genet. Genomes., 16, 1-11.

Zamudio F.D, Laytte R., Grallert C., Gamboa G.G., 2021. Nutritional status differentially affect yield and must composition of hybrids and $V$. vinifera varieties established under cold climate conditions. Ciência Téc. Vitiv., 36, 89-103.

Zhao F., Tausz M., De Kok L.J., 2008. Role of sulfur for plant production in agricultural and natural ecosystems. In: Sulfur metabolism in phototrophic organisms. 417-435. Hell R., Dahl C., Knaff D., Leustek T. (eds.). Springer, Dordrecht

Zlámalová T., Elbl J., Baroň M., Bělíková H., Lampíř L., Hlušek J., Lošák T., 2015. Using foliar applications of magnesium and potassium to improve yields and some qualitative parameters of vine grapes (Vitis vinifera L.). Plant Soil Environ., 61, 451-457. 